\title{
El Salvador publications in the Science Citation Index Expanded: subjects, authorship, collaboration and citation patterns
}

\author{
Julián Monge-Nájera ${ }^{1} \&$ Yuh-Shan $\mathrm{Ho}^{2 *}$ \\ 1. Laboratorio de Ecología Urbana, Vicerrectoría de Investigación, Universidad Estatal a Distancia, 2050 San José, Costa \\ Rica; julianmonge@gmail.com \\ 2. Trend Research Centre, Asia University, Taichung 41354, Taiwan; ysho@asia.edu.tw \\ * Correspondence
}

Received 28-III-2017. Corrected 07-VII-2017. Accepted 08-VIII-2017.

\begin{abstract}
In contrast with other countries of the Central America biodiversity "hotspot", El Salvador has received considerable attention from the scientometrics point of view. According to previous studies, the country is unusual in its strong concentration of research funds in the social sciences, and in the unexpectedly low productivity and visibility of its scientific institutions. We only found 788 publications with El Salvador authors in the Science Citation Index Expanded (SCI-EXPANDED) until 2015, mostly in English and about health, environment and agriculture. Articles have more authors than previously found for the rest of Central America. The fact that two historically important articles were written exclusively by Salvadoran scientists indicates the potential for high level science that the country has had at least since 1940. Scientific productivity and international collaboration are improving, but the whole productivity and impact of scientific institutions of El Salvador remain unknown because the country publishes 130 scientific journals that are not included in the SCI-EXPANDED. There is a clear need for a regional database covering Central American science and its citation. Rev. Biol. Trop. 65 (4): 1428-1436. Epub 2017 December 01.
\end{abstract}

Key words: Web of Science, Latin America, scientific productivity, most productive authors and institutions, research fields.

Central America is a tropical biodiversity "hotspot", and its scientific output has been studied in recent years by several authors, who found the region highly heterogeneous in scientific organization and productivity. For example, Costa Rica leads the region in total output and per capita production of articles included in the Science Citation Index Expanded (SCIEXPANDED), has a relatively large proportion of articles in Spanish and a high level of scientific independence (Monge-Nájera \& Ho, 2012; Nielsen-Muñoz, Azofeifa-Mora, \& Monge-Nájera, 2012). The situation in its neighbor Panama is contrasting: Panama publishes almost exclusively in English, depends to a significant extent on foreign scientists, and has nearly 100 Spanish language scientific journals that are not taken into account by the SCI-EXPANDED to measure its productivity and citation (Monge-Nájera \& Ho, 2015). This problem of articles that are widely read and cited by local scientists, but not included in impact factor measurements, is serious in tropical research, because most citations occur after the two-year window used by the SCI-EXPANDED to measure impact (MongeNájera \& Ho, 2016).

This article studies El Salvador, the smallest and most densely populated of Central American countries, which was greatly affected by a civil war that ended in 1992. Six years after the war ended, it was near the bottom of Latin American research founding (as percentage of the Gross Domestic Product, GDP; 
Albornoz, 2001). Nevertheless, El Salvador was more efficient than the regional giants (Brazil, Mexico, and Argentina) in its production of articles about agriculture (Fernández, Aguilar, \& Sánchez, 2002), and in the field of "social medicine" (i.e. the availability of health services to the lower-income class): Salvadorian physicians and psychologists supported research from their positions in the Pan-American Health Organization, with emphasis on the treatment of violence and torture victims (Iriart, Waitzkin, Breilh, Estrada, \& Merhy, 2002).

Later studies reviewed the position of El Salvador regarding social sciences, international collaboration, per capita production and internet presence. The country directs most research funds to the social sciences (Artiga-González, 2005). Most international collaboration is done with the USA but still the productivity in science in general is well below the Latin American average (Ríos Gómez \& Herrero Solana, 2005; Fernández et al., 2002; Albornoz, 2010). Even after correcting for population size, the scientific productivity of El Salvador is only half that of Costa Rica (Monge-Nájera \& Nielsen, 2005; Alger, Becerra-Posada, Kennedy, Martinelli, \& Cuervo, 2009). Nevertheless, the state provides significant funds for research, and in contrast with most Latin American countries, private institutions assign more funds than the government (Brid \& Ruiz-Nápoles, 2009).

Research done as part of international collaboration programs represented $14 \%$ according to Sancho (2006) and presence in Internet with technical documents was 8400 documents a decade ago (Aguillo, Ortega, Prieto, \& Granadino, 2007).

When the late $20^{\text {th }}$ century is compared with the $2^{\text {st }}$ century, El Salvador has a positive growth in production and citation that, in the case of epidemiology, reached $21 \%$ (Santa \& Herrero, 2010) but is still lower than its neighbors Honduras and Nicaragua (Ramos, González-Alcaide, Gascón, \& Gutiérrez, 2011; Barreto et al., 2012; Albuquerque et al., 2013).

A recent government report stated that $9 \%$ of education funds are used for research;
El Salvador has 30 universities and institutes, 13 research centers and 130 scientific journals, but that none is considered by the SCIEXPANDED when production and citation are recorded (Conacyt, 2014). Here we reviewed the literature from El Salvador in that database in the context of international science.

\section{MATERIAL AND METHODS}

We used the Science Citation Index Expanded (SCI-EXPANDED), Web of Science Core Collection, Thomson Reuters. We searched for documents with the word "El Salvador" in the address field and found 873 documents, published between 1900 and 2015 (Date of search: November $\left.24^{\text {th }}, 2016\right)$. Results were refined by countries/territories with El Salvador. In total, 788 documents were finally found as publications by authors from El Salvador. We reclassified articles from England, Scotland, Northern Ireland, and Wales as "United Kingdom" (UK).

This study also uses the indicator $T C_{2015}$ (total citations since publication to the end of 2015) (Chuang, Wang, \& Ho, 2011) because Web of Science total citations change with time. The use of the constant $T C_{2015}$ allows valid comparisons among studies.

\section{RESULTS}

For El Salvador, database records started in the decade of 1970 and the printed version of this study summarize them in figures and tables (Fig. 1, Fig. 2, Fig. 3, Fig. 4, Table 1, Table 2); (Fig. 5, Fig. 6, Fig. 7, Fig. 8, Fig. 9, Fig. 10, Fig. 11, Fig. 12 and Fig. 13 and Table 3, Table 4, (Table 5, Table 6, Table 7 and Table 8 appear as supplementary files in Digital Appendix 1 and Digital Appendix 2, respectively).

Top Web of Science categories for El Salvador publications are public, environmental and occupational health, with 90 articles (16\% of 562 articles), infectious diseases (8.2\%), and tropical medicine. 


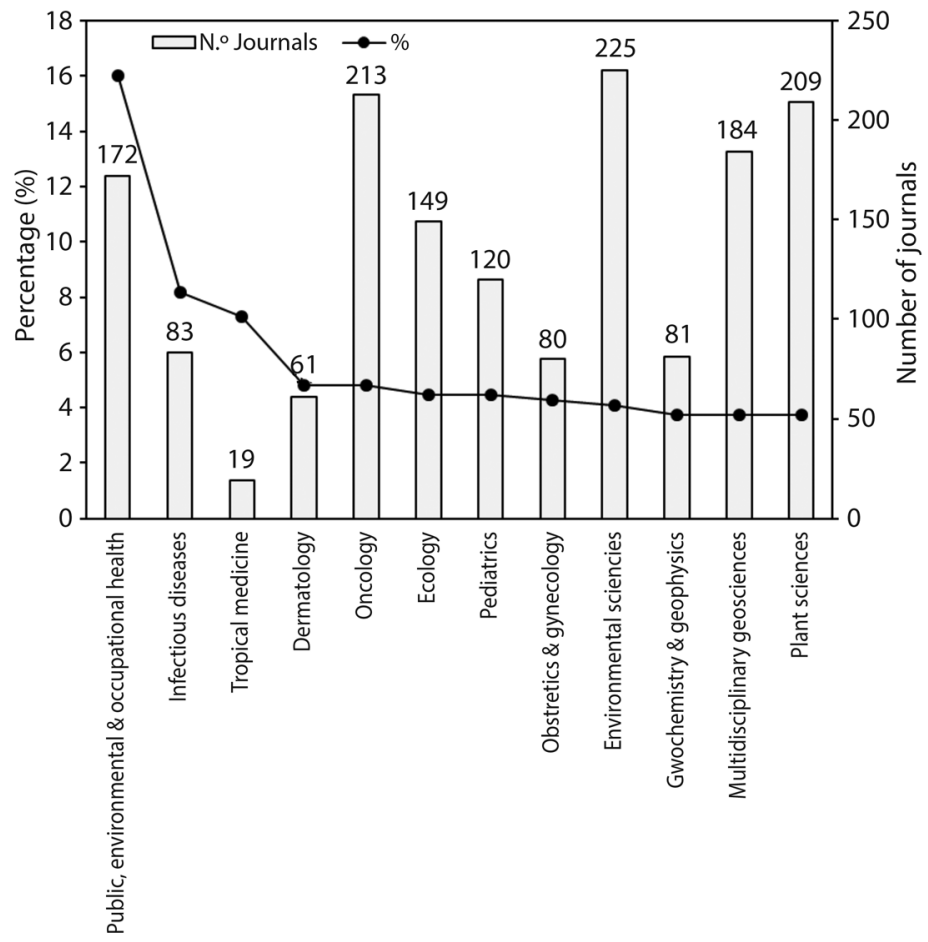

Fig. 1. Percentage of publications and number of journals from El Salvador (1972-2015), by Web of Science categories.

TABLE 1

Citations and authors of publications with researchers from El Salvador, according to document type (1972-2015)

\begin{tabular}{lccccc}
\multicolumn{1}{c}{ Document type } & $T P$ & $T C_{2015}$ & $C P P$ & $A U$ & $A U / T P$ \\
Article & 563 & 6775 & 12 & 4058 & 7.2 \\
Meeting abstract & 131 & 12 & 0.092 & 966 & 7.4 \\
Letter & 34 & 61 & 1.8 & 134 & 3.9 \\
Note & 22 & 77 & 3.5 & 51 & 2.3 \\
Editorial material & 20 & 110 & 5.5 & 119 & 6.0 \\
Review & 16 & 404 & 25 & 107 & 6.7 \\
Proceedings paper & 13 & 66 & 5.1 & 66 & 5.1 \\
Book review & 1 & 0 & 0 & 1 & 1.0 \\
News item & 1 & 5 & 5.0 & 16 & 16 \\
\hline
\end{tabular}

$T P$ : number of articles; $A U$ : Number of authors; $T C_{2015}$ : total citations since publication to the end of $2015 ; C P P$ citations per paper $\left(T C_{2015} / T P\right)$.

The mean number of authors per paper is about six for the three most important types of publication, namely, articles, meeting abstracts, and reviews (Table 1). Altogether 563 articles were selected for further study.

The main language of El Salvador articles in the database is English, and English articles receive more citations in the database (Table 2 ). The number of authors per paper has tripled and the number of references and pages per paper has doubled since the 1970's (Table 3).

Citations in this particular database peak around the third year and may have a revival after 40 years (Fig. 2). 


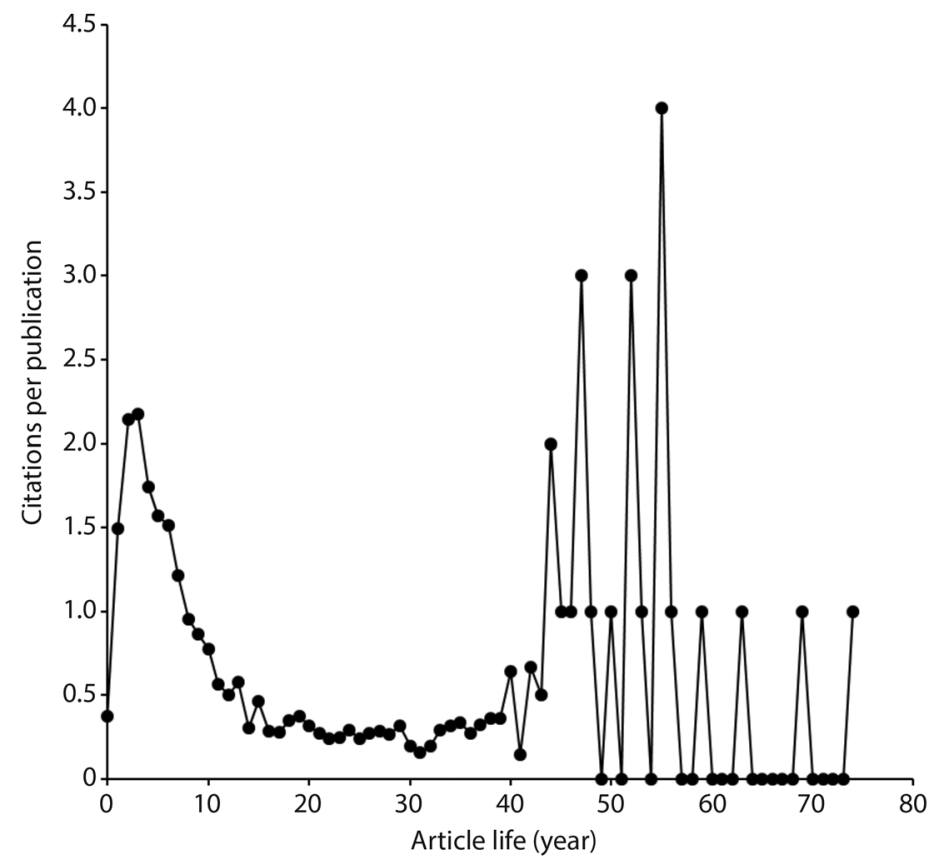

Fig. 2. Distribution of citations versus article age in years for articles with El Salvador authors or coauthors (1972-2015).

TABLE 2

Citations and authors according to document language, from El Salvador (1972-2015)

\begin{tabular}{lccccc}
\multicolumn{1}{c}{ Language } & $T P$ & $T C_{2015}$ & $C P P$ & $A U$ & $A U / T P$ \\
English & 516 & 6658 & 13 & 3827 & 7.4 \\
Spanish & 41 & 105 & 2.6 & 206 & 5.0 \\
Portuguese & 5 & 7 & 1.4 & 21 & 4.2 \\
French & 1 & 5 & 5.0 & 4 & 4.0 \\
\hline
\end{tabular}

$T P$ : number of articles; $A U:$ Number of authors; $T C_{2015}$ : total citations since publication to the end of 2015; $C P P$ citations per paper $\left(T C_{2015} / T P\right)$.

Article coverage in the database peaked in the mid 1970s and has grown steadily since 1990; similarly, citations have a small growth tendency in recent years but oscillate widely around a mean of 10 citations per year per article (Fig. 3).

The three most cited articles are medical: a set of international classification for pediatric diseases; an international nosocomial infection control report; and an analysis of the epidemiology of American cutaneous Leishmaniasis (Table 4).
Two of the three historically most cited health studies are exclusively Salvadoran in origin and deal with infections and Leiomyoma (Table 5). The first, by León Ávila Jr. (Hospital Rosales de San Salvador), published in 1941, describes a new method to cure bacterial infections of the joints. The second, by Orlando Orellana Díaz and Enrique Hernández Pérez, dermatologists at Universidad de El Salvador, published in 1983, analyzed 35 cases of leiomyomas (benign smooth muscle tumors) and leiomyosarcomas (soft tissue 


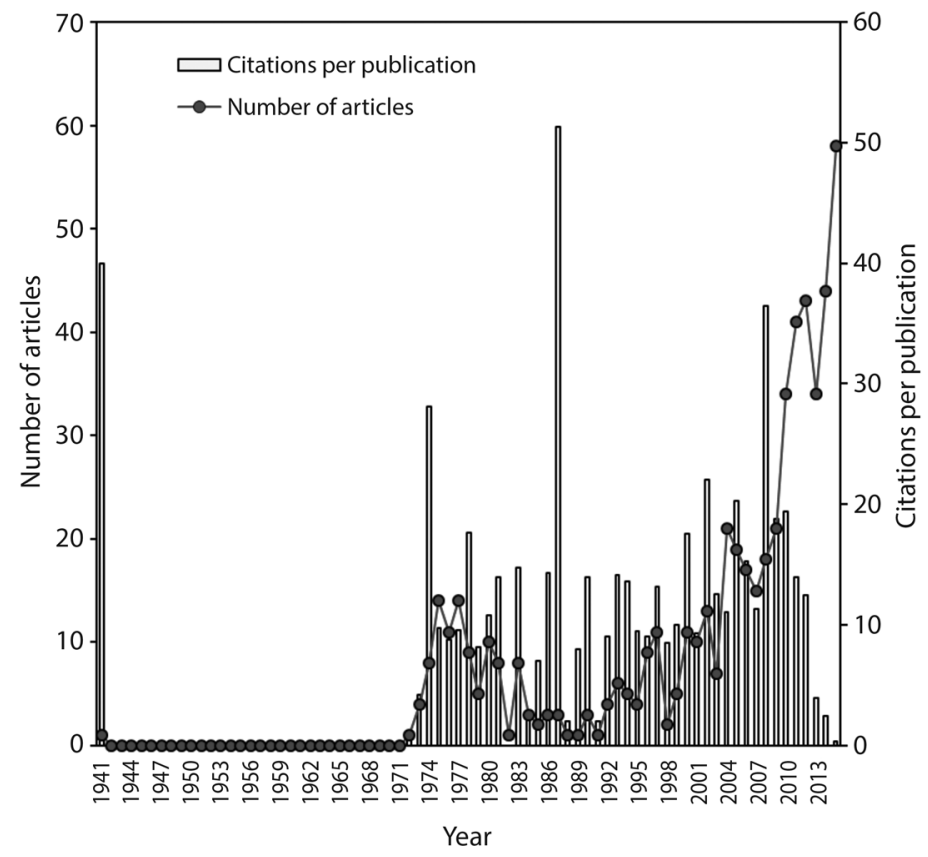

Fig. 3. Distribution of articles and citations per publication from 1941 through 2015, with authors or coauthors from El Salvador.

cancer) and concluded that they were rare, but more common in women than in men. Despite their age, these articles continue to be cited in the literature and actually seem to have been "rediscovered" in recent years (Table 5).

The four top cited articles have been increasingly cited in recent years, even though two are from the 1970s (Fig. 8) and have a lifespan of over 40 years (Fig. 9).

Generally, the most cited articles decrease in citation after two years and may have a revival in citation in recent years (Fig. 10, Fig. 11 and Fig. 12). The top cited institutions have increased in citation in recent years (Fig. 13) as have the top cited Web of Science topics (Fig. 14).

The most prolific institutions in the country are the Universidad de El Salvador, Hospital Benjamín Bloom, and the Ministerio de Salud (Table 7).

The top three journals by number of publications are the American Journal of Tropical Medicine and Hygiene (USA), the Revista de
Biología Tropical (Costa Rica) and Neurorehabilitation (Netherland) (Table 8).

Overall, studies led by foreigners receive twice as many citations as those from Salvadoran scientists (Fig. 4; Table 2).

Most records corresponded to articles, distantly followed by meeting abstracts, while all other publication types were scarce. Citations, on the other hand, are dominated by review articles, while letters were at the bottom of citations (Fig. 5).

Previously to 1990 there are few collaboration papers in the database, but they have grown continuously since 2000 , led clearly by the USA, and followed by Mexico, Spain and Guatemala (Fig. 6). Locally, collaboration is done mostly with geographic neighbors, and is increasing in recent years (Fig. 7; Table 6).

\section{DISCUSSION}

The scientific output of El Salvador that is covered in the SCI-EXPANDED is mostly 


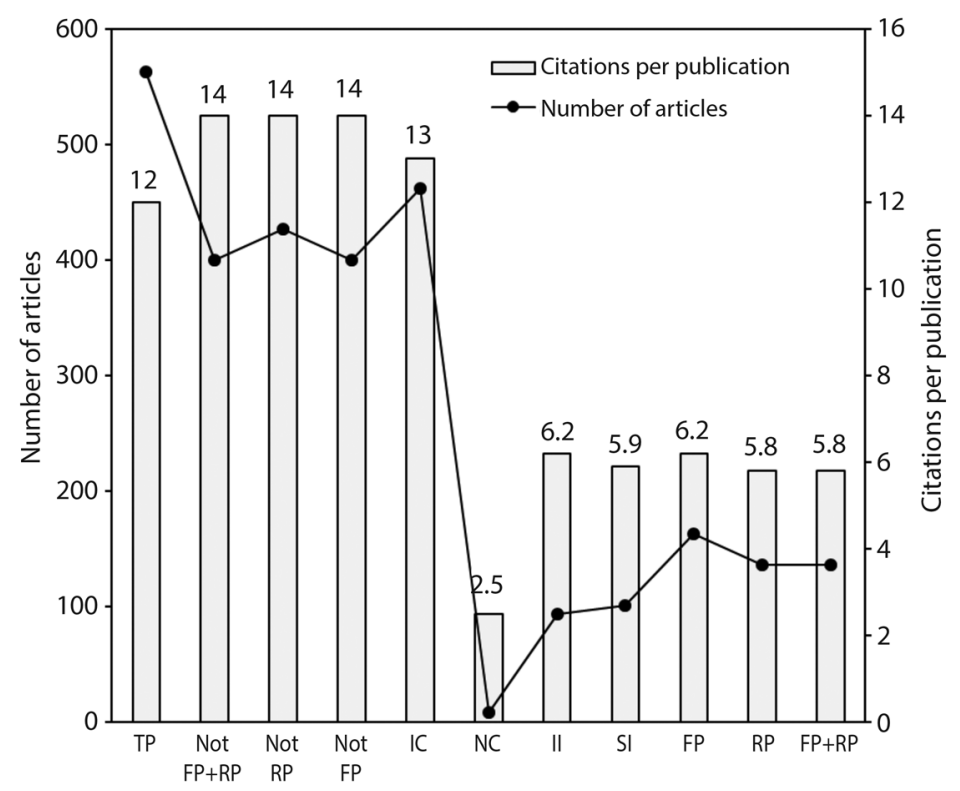

Fig. 4. Productivity and citation according to nationality in local and internationally produced articles with El Salvador authors or coauthors (1972-2015). TP: total articles. Not FP+RP: both first and corresponding authors are not from El Salvador. Not RP: corresponding author is not from El Salvador. Not FP: first author is not from El Salvador. IC: internationally collaborative papers. NC: nationally collaborative papers. II: institutional independent papers. SI: E1 Salvador independent papers. FP: first author is from El Salvador. RP: corresponding author is from El Salvador. FP+RP: both first and corresponding authors are from El Salvador.

composed of English language articles, a pattern that resembles other Central American countries (Monge-Nájera \& Ho, 2015).

The importance of health research is appropriate for a tropical country (Vargas, Dovalina, \& de Arenas, 2004; Fernández, Sancho, Morillo, De Filippo, \& Gómez, 2005; Alger et al., 2009; Ramos et al., 2011).

Despite the strong financial support given to social sciences in El Salvador (Iriart et al., 2002), it does not have a significant presence in the SCI-EXPANDED, but this is explained by the focus of that index in the natural sciences (Artiga-González, 2005; Brid \& Ruiz-Nápoles, 2009; Conacyt, 2014).

The citation rate of around 12 citations per paper is high, but lower than Costa Rica's which is 18 (Monge-Nájera \& Ho, 2012). The higher citation of health related papers also fits a well known trend because of the high world productivity in this area (Monge-Nájera \& Ho, 2012, 2016). El Salvador publications are mostly cited after the SCI-EXPANDED stops counting citations, thus severely underestimating impact, a problem that affects all countries outside Europe and North America (Monge-Nájera \& Ho, 2012).

Studies led by foreigners are more cited than those from Salvadoran scientists because foreign researchers have better access to SCIEXPANDED journals; and review articles are more cited because they summarize important amount of information; all of these results are similar to previous findings in neighboring countries (Monge-Nájera \& Ho, 2012; 2016).

The top institutions have increased in citation in recent years, as have the top cited Web of Science topics. This result also fits a pattern reported before that indicates the development of a stronger scientific apparatus in Central America in recent years (Monge-Nájera \& Ho, 2016). The "rediscovery" of papers that become highly cited again after decades, is unusual and, in our study of Central American 
science, currently unique to El Salvador: a topic that deserves further study.

The relatively high number of authors per paper, 6.2 , is higher than previously found for the rest of Central America, where three authors per paper is more frequent (NielsenMuñoz et al., 2012). However, the increase in article length and in the number of authors per article is not surprising, considering the increasing complexity of scientific studies (Aboukhalil, 2014).

The fact that two historically important articles were written exclusively by Salvadoran scientists indicates the potential for high level science of the country at least since 1940 , while the publication of most of their productivity in the USA, Europe and Costa Rica also reflects the usual scientific influence on Central America (Monge-Nájera \& Ho, 2012).

The increasing importance of international collaboration, and the tendency to do so with geographically close countries, also fit a well known pattern in the area, reported, for example, for Costa Rica (Albornoz, 2001; Ríos Gómez \& Herrero Solana, 2005, Monge-Nájera \& Ho, 2012). Nevertheless, the international collaboration of El Salvador is unusually low for the region (Sancho, 2006) and needs further analysis from future researchers.

An important limitation of our study is that the 130 scientific journals published in El Salvador are not included in the SCI-EXPANDED (Conacyt, 2014), so we do not know what is published in those journals or who cites them. They probably represent more articles than those covered in our study; our results are only valid for publications in journals covered in the SCI-EXPANDED which focuses in North America and Europe. There is a strong need for a bibliometric study of that large number of El Salvador journals.

Nevertheless, the general pattern of El Salvador research is positive, with a real growth in quantity and quality, and greater coverage in First World databases. This tendency has been sustained for more than a decade (Santa \& Herrero, 2010) and should reduce the clear lag that the country has had from the rest of Central America (Barreto et al., 2012).

To keep improving, El Salvador needs to raise its scientific standards (Urquia-Osorio, Henríquez-Marquez, Vásquez-Bonilla, Estrada-Mendoza, \& Rodríguez-Morales, 2014) and to make a deep cultural change towards respect and admiration for scientific achievement (Orantes, 2015). We hope this study provides Salvadoran scientists with enough useful data to begin that change.

\section{ACKNOWLEDMENTS}

We thank Carlos Morales and Francisco Hernández (Universidad de Costa Rica) for suggestions to improve an earlier draft.

\section{RESUMEN}

Publicaciones de El Salvador en el Science Citation Index Expanded: temas, autoría, colaboración y patrones de citación. En contraste con otros países del "núcleo de biodiversidad" que es Centroamérica, El Salvador ha recibido considerable atención desde el punto de vista bibliométrico. Según estudios anteriores, el país es inusual por su fuerte concentración de fondos de investigación en las ciencias sociales, su baja productividad y la poca visibilidad internacional de sus instituciones científicas. Sólo hallamos 788 publicaciones con autores de El Salvador en el Science Citation Index Expanded (SCI-EXPANDED) hasta 2015, principalmente en inglés y sobre salud, ambiente y agricultura. Los artículos tienen más autores que en el resto de Centroamérica. El hecho de que dos artículos de importancia histórica fueron escritos exclusivamente por científicos salvadoreños indica el gran potencial científico del país desde 1940. La productividad científica y la colaboración internacional están mejorando, pero la gran mayoría de la productividad y del impacto de las instituciones salvadoreñas resultan desconocidas porque el país publica 130 revistas científicas que no están incluidas en el SCI-EXPANDED. Existe una clara necesidad de una base de datos regional que cubra la ciencia centroamericana y su impacto real.

Palabras clave: América Latina, productividad científica, autores e instituciones más productivos, campos de investigación. 


\section{REFERENCES}

Aboukhalil, R. (2014). The rising trend in authorship. The Winnower, 2, e141832. doi:10.15200/ winn.141832.26907

Aguillo, I. F., Ortega, J. L., Prieto, J. A., \& Granadino, B. (2007). Indicadores Web de actividad científica formal e informal en Latinoamérica. Revista Española de Documentación Científica, 30(1), 49-60.

Albornoz, M. (2001). Política Científica y Tecnológica Una visión desde América Latina. Revista Iberoamericana de Ciencia, Tecnología, Sociedad e Innovación, $1,1-19$.

Albornoz, M. (Ed.). (2010). Principales Indicadores de Ciencia y Tecnología Iberoamericanos / Interamericanos. Buenos Aires, Argentina: Red Iberoamericana de Indicadores de Ciencia y Tecnología. Centro de Estudios sobre Ciencia, Desarrollo y Educación Superior.

Albuquerque, U. P., Silva, J. S., Campos, J. L. A., Sousa, R. S., Silva, T. C., \& Alves, R. R. N. (2013). The current status of ethnobiological research in Latin America: gaps and perspectives. Journal of Ethnobiology and Ethnomedicine, 9(1), 72. doi: 10.1186/1746-4269-9-72

Alger, J., Becerra-Posada, F., Kennedy, A., Martinelli, E., \& Cuervo, L. G. (2009). Sistemas nacionales de investigación para la salud en América Latina: una revisión de 14 países. Revista Panamericana de Salud Publica, 26(5), 447-57.

Artiga-González, Á. (2005). La ciencia política en El Salvador: sus primeros pasos. Revista de Ciencia Política (Santiago), 25(1), 162-170. doi: 10.4067/ S0718-090X2005000100012

Avila, Jr., L. (1941), Primary pyogenic infection of the sacro-iliac articulation. A new approach to the joint - Report of seven cases. Journal of Bone and Joint Surgery, 23(4), 922-928.

Barreto, S. M., Miranda, J. J., Figueroa, J. P., Schmidt, M. I., Munoz, S., Kuri-Morales, P. P., \& Silva, J. B. (2012). Epidemiology in Latin America and the Caribbean: current situation and challenges. International Journal of Epidemiology, 41(2), 557-571. doi: 10.1093/ije/dys017

Brandling-Bennett, A. D., Anderson, J., Fuglsang, H., \& Collins, R. (1981), Onchocerciasis in Guatemala. Epidemiology in fincas with various intensities of infection. American Journal of Tropical Medicine and Hygiene, 30(5), 970-981.

Breeland, S. G., Jeffery, G. M., Lofgren, C. S., \& Weidhaas, D. E. (1974). Release of chemosterilized males for control of Anopheles Albimanus in El-Salvador. I. Characteristics of test site and natural population. American Journal of Tropical Medicine and Hygiene, 23(2), 274-281.
Brid, M., \& Ruiz Nápoles, P. (2009). La educación superior y el desarrollo económico en América Latina. México, D. F.: CEPAL, Naciones Unidas.

Chuang, K. Y., Wang, M. H., \& Ho, Y. S. (2011), Highimpact papers presented in the subject category of water resources in the Essential Science Indicators database of the Institute for Scientific Information. Scientometrics, 87(3), 551-562. doi: 10.1007/ s11192-011-0365-2

Collins, R. C., Brandling-Bennett, A. D., Holliman, R. B., Campbell, C. C., \& Darsie, R. F. (1980). Parasitological diagnosis of onchocerciasis: Comparisons of incubation media and incubation times for skin snips. American Journal of Tropical Medicine and Hygiene, 29(1), 35-41.

Conacyt. (2014). Indicadores de ciencia y tecnología El Salvador 2014. San Salvador: Consejo Nacional de Ciencia y Tecnología (Conacyt)

Fernández, M. T., Sancho, R., Morillo, F., De Filippo, D., \& Gómez, I. (2005). Indicadores de especialización temática de los países de América Latina. Madrid: CINDOC.

Fernández, Ó. S., Aguilar, G. S., \& Sánchez, M. V. G. (2002). Medición de la producción científica en América Latina y el Caribe en el campo agrícola y afines: un estudio bibliométrico. Revista Española de Documentación Científica, 25(2), 151-161.

Hernández-Pérez, E., \& Cruz, F. A. (1976), Clear cell hydradenocarcinoma. Report of an unusual case. Dermatologica, 153(4), 249-252.

Iriart, C., Waitzkin, H., Breilh, J., Estrada, A., \& Merhy, E. E. (2002). Latin American social medicine: contributions and challenges. Revista Panamericana de Salud Pública, 12(2), 128-136. doi: 10.1590/ S1020-49892002000800013

Monge-Nájera, J., \& Ho, Y. S. (2012). Costa Rica Publications in the Science Citation Index Expanded: A bibliometric analysis for 1981-2010. Revista de Biología Tropical, 60(4), 1649-1661. doi: 10.15517/ rbt.v60i4.2158

Monge-Nájera, J., \& Ho, Y. S. (2015). Bibliometry of Panama publications in the Science Citation Index Expanded: publication type, language, fields, authors and institutions. Revista de Biología Tropical, 63(4), 1255-1266. doi: 10.15517/rbt.v63i4.21112

Monge-Nájera, J., \& Ho, Y. S. (2016). Bibliometry of the Revista de Biología Tropical/International Journal of Tropical Biology and Conservation: document types, languages, countries, institutions, citations and article lifespan. Revista de Biología Tropical, 64(3), 12231235. doi: 10.15517/rbt.v64i3.22142

Monge-Nájera, J., \& Nielsen, V. (2005). The countries and languages that dominate biological research 
at the beginning of the 21 st century. Revista de Biología Tropical, 53(1-2), 283-294.

Nielsen-Muñoz, V., Azofeifa-Mora, A. B., \& Monge-Nájera, J. (2012). Bibliometry of Costa Rica biodiversity studies published in the Revista de Biología Tropical/ International Journal of Tropical Biology and Conservation (2000-2010): the content and importance of a leading tropical biology journal in its 60th Anniversary. Revista de Biologia Tropical, 60(4), 1405-1413.

Orantes, B. R. (2015). Diagnóstico de la producción científica y actividad investigadora del profesorado de las instituciones de educación superior en El Salvador (Ph.D. Thesis). Universidad de Granada, España.

Orellana-Díaz, O., \& Hernández-Pérez, E. (1983), Leiomyoma cutis and leiomyosarcoma: A 10-year study and a short review. Journal of Dermatologic Surgery and Oncology, 9(4), 283-287.

Ozen, S., Pistorio, A., Iusan, S. M., Bakkaloglu, A., Herlin, T., Brik, R., Buoncompagni, A., (...), \& Ruperto, N. (2010). EULAR/PRINTO/PRES criteria for HenochSchönlein purpura, childhood polyarteritis nodosa, childhood Wegener granulomatosis and childhood Takayasu arteritis: Ankara 2008. Part II: Final classification criteria. Annals of the Rheumatic Diseases, 69(5), 798-806. doi: 10.1136/ard.2009.116657
Ramos, J. M., González-Alcaide, G., Gascón, J., \& Gutiérrez, F. (2011). Mapping of Chagas disease research: analysis of publications in the period between 1940 and 2009. Revista da Socieda de Brasileira de Medicina Tropical, 44(6), 708-716. doi: 10.1590/ S0037-86822011005000060

Ríos Gómez, C., \& Herrero Solana, V. (2005). La producción científica latinoamericana y la ciencia mundial: una revisión bibliográfica (1989-2003). Revista Interamericana de Bibliotecología, 28(1), 43-61.

Sancho, R. (2006). Indicadores de colaboración científica inter-centros en los países de América Latina. Interciencia, 31(4), 284-292.

Santa, S., \& Herrero Solana, V. (2010). Producción científica de América Latina y el Caribe: una aproximación a través de los datos de Scopus (1996-2007). Revista Interamericana de Bibliotecología, 33(2), 379-400.

Urquia-Osorio, H., Henríquez-Marquez, K. I, VásquezBonilla, W. O., Estrada-Mendoza, A. J., \& Rodríguez-Morales, A. J. (2014). Producción científica de decanos de medicina y salud de universidades centroamericanas. Salud Pública de México, 56(3), 243-244.

Vargas, M. A., Dovalin, M. P., \& de Arenas, J. L. (2004). La investigación agrícola en América Latina y el Caribe desde una perspectiva bibliométrica. Anales de Documentación, 7, 29-38.

See Digital Appendix at: / Ver Apéndice digital en:

revistas.ucr.ac.cr 